\title{
KINERJA GURU DITINJAU DARI PENGARUH LINGKUNGAN KERJA DAN PENGHARGAAN
}

\author{
Merry $^{1}$, Edi Harapan ${ }^{2}$, Rohana $^{3}$ \\ Mahasiswa Universitas PGRI ${ }^{1}$, Dosen Universitas PGRI ${ }^{2}$, \\ Dosen Universitas PGRI ${ }^{3}$ \\ Jalan Jenderal Ahmad Yani Lorong Gotong Royong No. 9/10 Palembang
}

\section{Sur-el: Merrysyaripuddin9498@gmail.com ${ }^{1}$, ehara205@gmail.com², rohanapgripalembang@gmail.com ${ }^{3}$}

Article info

Article history:

Received: $16-02-2020$

Revised : 04-04-2020

Accepted: 17-05-2020

\begin{abstract}
A B S T R A C T
This research aims to determine the effect of the work environment and rewards on teachers's performance at SMPN 1 Indralaya. This research uses quantitative methods with correlational type of research. The research population was 45 people, namely the teachers at SMPN 1 Indralaya. The number of research samples were 40 people. The sampling technique in this study is simple random sampling. Data collection techniques using a questionnaire. Data were analyzed using simple linear regression test analysis techniques and multiple linear regression. Research results show that: (1) The work environment has no significant effect on the teachers's performance at SMPN 1 Indralaya. (2) The rewards has a significant effect on the teachers's performance at SMPN 1 Indralaya (3) Work environment and rewards together have a significant effect on the teachers's performance at SMPN 1 Indralaya.
\end{abstract}

Keywords:

Teachers's

Performance, Work

Environment,

Rewards

Kata Kunci:

Kinerja Guru, Lingkungan Kerja, Penghargaan
Penelitian ini bertujuan untuk mengetahui pengaruh lingkungan kerja dan penghargaan terhadap kinerja guru di SMPN 1 Indralaya. Penelitian ini menggunakan metode kuantitatif dengan jenis penelitian korelasional. Populasi penelitian sebanyak 45 orang yaitu guru-guru di SMPN 1 Indralaya. Jumlah sampel penelitian sebanyak 40 orang. Teknik pengambilan sampel dalam penelitian ini adalah simple random sampling. Teknik pengumpulan data menggunakan kuesioner. Data dianalisis menggunakan teknik analisis uji regresi linier sederhana dan regresi linier ganda. Hasil Penelitian menunjukan bahwa: (1) Lingkungan kerja tidak berpengaruh signifikan terhadap kinerja guru SMPN 1 Indralaya. (2) Penghargaan berpengaruh signifikan terhadap kinerja guru SMPN 1 Indralaya dan (3) Lingkungan kerja dan penghargaan secara bersama-sama berpengaruh signifikan terhadap kinerja guru SMPN 1 Indralaya.
Direktorat Riset dan Pengabdian Masyarakat Universitas Bina Darma. 


\section{JURNAL ILMIAH \\ BINA EDUKASI \\ ISSN 1979-8598 E-ISSN: 2655-8378 \\ http://journal.binadarma.ac.id/index.php/jurnalbinaedukasi \\ Vol. 13, No. 1, Juni 2020, 27--40}

\section{PENDAHULUAN}

Guru merupakan salah satu aspek utama dalam dunia pendidikan. Guru adalah pendidik profesional dengan tugas utama mendidik, mengajar, membimbing, mengarahkan, melatih, menilai, dan mengevaluasi peserta didik pada pendidikan anak usia dini jalur pendidikan formal, pendidikan dasar, dan pendidikan menengah. Guru mempunyai kedudukan sebagai tenaga profesional pada jenjang pendidikan dasar, pendidikan menengah, dan pendidikan anak usia dini pada jalur pendidikan formal yang diangkat sesuai dengan peraturan perundang-undangan (Undang-undang Nomor 14 Tahun 2005 Tentang Guru dan Dosen). Kedudukan guru sebagai tenaga profesional bertujuan untuk melaksanakan sistem pendidikan nasional dan mewujudkan tujuan pendidikan nasional, yaitu berkembangnya potensi peserta didik agar menjadi manusia yang beriman dan bertakwa kepada Tuhan Yang Maha Esa, berakhlak mulia, sehat, berilmu, cakap, kreatif, mandiri, serta menjadi warga negara yang demokratis dan bertanggung jawab.

Guru ibarat mesin penggerak bagi segala hal yang terkait dengan aktivitas ilmiah dan akademis di sekolah. Tanpa guru, tak mungkin sebuah lembaga pendidikan disebut sekolah. Sebab itu, di negara-negara maju, sebelum mendirikan sebuah sekolah, hal yang dididik dan dilatih terlebih dahulu adalah guru. Setelah para gurunya ditentukan, baru sekolah didirikan, bukan sebaliknya. Demikian pentingnya guru ini hingga tidak sedikit sekolah menjadi terkenal karena kemasyhuran para guru yang bekerja di dalamnya. Dalam posisi sebagai "jantung" sekolah, guru sangat menentukan mutu pendidikan dan lulusan yang dilahirkan sekolah tersebut, di samping secara umum kualitas sekolah itu sendiri. Jika para gurunya bermutu tinggi, maka kualitas sekolah tersebut juga akan tinggi, demikian pula sebaliknya. Sebaik apapun program pendidikan yang dicanangkan, bila tidak didukung oleh para guru bermutu tinggi, maka akan berakhir pada hasil yang tidak memuaskan. Hal itu karena untuk menjalankan program pendidikan yang baik diperlukan para guru yang juga bermutu baik. Dengan memiliki guru-guru yang baik dan bermutu tinggi, sekolah dapat merumuskan program pengajaran serta kurikulum termodern untuk menjamin lahirnya lulusan-lulusan yang berprestasi dan berkualitas istimewa.

Selain mutu dan kualitas guru yang diperhatikan, hal lain yang menjadi penting adalah terkait kinerja guru. Kesuksesan dan kinerja lembaga pendidikan (sekolah) bisa dilihat dari kinerja yang telah dicapai oleh gurunya, oleh sebab itu biasanya sekolah menuntut agar para gurunya mampu menampilkan kinerja yang optimal karena baik buruknya kinerja guru akan berpengaruh pada kinerja dan keberhasilan sekolah secara keseluruhan di mata masyarakat. Bagi guru yang telah diikutsertakan dalam pengembangan keprofesian, tetapi masih memiliki kinerja yang rendah dan tidak memenuhi persyaratan, maka guru yang bersangkutan akan dikurangi 


\section{JURNAL ILMIAH \\ BINA EDUKASI \\ ISSN 1979-8598 E-ISSN: 2655-8378 \\ http://journal.binadarma.ac.id/index.php/jurnalbinaedukasi \\ Vol. 13, No. 1, Juni 2020, 27--40}

beban kerjanya. Guru yang mempunyai kinerja rendah wajib mengikuti pembinaan pengembangan keprofesian berkelanjutan (Permendiknas Nomor 35 Tahun 2010).

Faktor-faktor yang dapat memengaruhi kinerja akan membuat manajemen organisasi (sekolah) dapat mengambil berbagai kebijakan yang diperlukan, sehingga dapat meningkatkan kinerja guru yang sesuai dengan harapan dan tujuan organisasi. Oganisasi tidak hanya sematamata mengejar pencapaian produktivitas yang tinggi saja, tetapi juga lebih memperhatikan kinerja dalam proses pencapaiannya. Dengan demikian kinerja (performance) merupakan faktor kunci bagi setiap individu dan organisasi dalam pencapaian produktivitas. Widyasari dalam Edwardin (2006) kinerja adalah suatu hasil dimana orang, sumber-sumber yang ada di lingkungan kerja tertentu secara bersama membawa hasil akhir yang didasarkan tingkat mutu dan standar yang telah ditetapkan. Banyak aspek yang mempengaruhi keberhasilan suatu kinerja seperti kejelasan peran, tingkat kompetensi, keadaan lingkungan kerja, dan faktor lainnya seperti nilai, budaya, imbalan dan penghargaan, serta faktor internal individu, misalnya motivasi dan kepuasan kerja merupakan hal yang tidak boleh diabaikan. Sebagai tenaga profesional kependidikan di lembaga pendidikan (sekolah), guru memiliki tingkat kepuasan kerja yang berbeda antara guru satu dengan lainnya. Hal ini kelak akan berakibat adanya perbedaan kinerja guru dalam meningkatkan mutu pendidikan.

Kinerja guru dalam pembelajaran merupakan faktor utama dalam pencapaian tujuan pendidikan, karena guru merupakan ujung tombak dalam dunia pendidikan.Tinggi rendahnya kualitas kinerja guru berakibat pada hasil belajar siswa di sekolah. Menurut Usman (2009) Peningkatan kinerja guru dalam pembelajaran dipengaruhi beberapa faktor antara lain (1) gaji, (2) sarana prasarana, (3) kondisi lingkungan kerja fisik, dan (4) kepemimpinan.

Berdasarkan uraian di atas, dapat disimpulkan bahwa salah satu faktor yang memengaruhi kinerja guru adalah lingkungan kerja. Menurut laporan produktivitas Intenational Labour Office (ILO), hal pertama yang harus diusahakan dapat memperbaiki kinerja guru adalah menjamin agar guru dapat melaksakan tugasnya dalam keadaan memenuhi syarat. Dengan demikian, guru dapat melaksanakan tugasnya tanpa mengalami ketegangan-ketegangan atau dengan kata lain pemerintah harus menyediakan lingkungan kerja yang baik bagi guru. Dengan adanya lingkungan kerja yang baik dapat menciptakan hubungan kerja yang kondusif antara orang-orang yang ada didalamnya (Barnawi dan Arifin, 2014).

Mulyasa (2013) mengatakan bahwa untuk menciptakan lingkungan kerja yang kondusif sedikitnya diperlukan dua hal, yakni guru itu sendiri serta hubungan baik antara guru dengan orang tua dan masyarakat sekitarnya. Selaras dengan pendapat tersebut kondisi kerja yang mendukung sangat dibutuhkan yaitu lingkungan kerja yang nyaman untuk mereka. Lingkungan kerja yang baik akan memfasilitasi mereka untuk kerja lebih baik pula. Mereka lebih menyukai kondisi fisik yang tidak berbahaya atau nyaman. Disamping itu, sebagian besar menyukai tempat 


\section{JURNAL ILMIAH \\ BINA EDUKASI \\ ISSN 1979-8598 E-ISSN: 2655-8378 \\ http://journal.binadarma.ac.id/index.php/jurnalbinaedukasi \\ Vol. 13, No. 1, Juni 2020, 27--40}

kerja yang relatif dekat (Usman, 2009). Apabila lingkungan kerja disekolah menyenangkan maka akan merangsang guru memiliki tanggung jawab melaksanakn tugas dan kewajibannya dengan baik dan senang hati (Supardi, 2013).

Tinggi rendahnya kinerja guru berkaitan juga dengan tingkat kesejahteraan guru. Rendahnya kesejahteraan guru mempunyai peranan dalam membuat rendahnya kualitas pendidikan di Indonesia (Harapan, 2018). Berdasarkan hasil survei Federasi Guru Independent Indonesia (FGII) pada pertengahan tahun 2015, idealnya seorang guru menerima gaji bulanan sebesar Rp 3.000.000,00 (tiga juta rupiah). Pada kenyataannya masih banyak guru di indonesia yang menerima gaji di bawah Rp 3.000.000,00 (tiga juta rupiah), bahkan ada guru honorer yang menerima gaji di bawah Rp 1.000.000,00 (satu juta rupiah) per bulan. Pemberian gaji yang rendah mengindikasikan rendahnya penghargaan terhadap profesi guru.

Selain faktor lingkungan kerja yang dapat memengaruhi kinerja guru, penghargaan termasuk faktor instrinsik dan ekstrinsik yang memengaruhi kinerja guru. Penghargaan mencakup unsur kuantitatif seperti gaji, upah dan lain-lain, bukan hanya unsur kuantitatif yang berpengaruh terhadap penghargaan, tetapi unsur lain yang bersifat kualitatif seperti kesempatan melaksanakan tanggung jawab yang lebih besar, peluang dalam berkarir, kesempatan belajar dan berkembang, mendapatkan kualitas kehidupan yang layak dalam organisasi dan lain-lain (Nnaji-Ihedinmah \& Egbunike, 2015).

Penghargaan merupakan salah satu faktor penting yang memengaruhi kinerja karena sebagian besar waktu manusia dihabiskan di tempat kerja. Menurut Rivai (2005) ada dua faktor yang memengaruhi penghargaan yaitu lingkungan eksternal dan lingkungan internal. Lingkungan eksternal adalah faktor-faktor yang memengaruhi penghargaan yang berasal dari luar instansi, seperti peluang pekerjaan, keadaan ekonomi, regulasi yang dibuat pemerintah, dan serikat pekerja, sedangkan lingkungan internal adalah hal-hal yang berkaitan dengan kondisi dalam instansi dan turut memengaruhi penghargaan tersebut.

Berdasarkan pengamatan peneliti di Sekolah Menengah Pertama Negeri (SMPN) 1 Indralaya bahwa sekolah sebagai lingkungan kerja guru dalam melakukan aktivitas belajar dan mengajar, masih belum optimal dikarenakan posisi SMPN Negeri 1 Indralaya yang berada persis di pinggir Jalan Lintas Timur Sumatera yang sangat padat dengan lalu lintas kendaraan sehingga sering kali terjadi kebisingan suara. Identifikasi masalah pada penelitian ini, yaitu (1) Salah satu upaya dalam rangka meningkatkan mutu pendidikan adalah perlunya meningkatkan kinerja guru. Kinerja guru yang baik akan memberi efek antara lain perbaikan institusi pendidikan dan peningkatan prestasi belajar siswa, akan tetapi seringkali yang kita temui sebaliknya, guru tidak menjalankan tugas dan fungsinya sebagaimana mestinya; (2) Guru dianggap sebagai salah satu pusat keberhasilan pendidikan, sebagai orang yang berperan dalam pencapaian tujuan pembelajaran khususnya di dalam kelas, oleh karena itu guru memiliki peran yang sangat penting 


\section{JURNAL ILMIAH \\ BINA EDUKASI \\ ISSN 1979-8598 E-ISSN: 2655-8378 \\ http://journal.binadarma.ac.id/index.php/jurnalbinaedukasi \\ Vol. 13, No. 1, Juni 2020, 27--40}

dalam proses pembelajaran di kelas, akan tetapi sering kali guru menunjukkan hal yang berbeda, misalnya guru datang terlambat, siswa hanya disuruh mencatat, dan hal lain yang bertentangan dengan peran guru sebagai tenaga pendidik; (3) Guru yang tidak melaksankan tugas dan fungsinya dengan baik terkait proses belajar dan mengajar, akan sangat mempengaruhi keberhasilan pencapian tujuan pembelajaran di kelas. Tugas dan fungsi guru yang sering terabaikan misalnya tidak menyusun rencana pelaksanaan pembelajaran; (4) Dalam rangka untuk memengaruhi peningkatan kinerja guru di sekolah, ada berbagai hal yang dapat dilakukan, mulai dari menciptakan lingkungan kerja yang kondusif agar guru merasa nyaman dan betah berada di sekolah, selanjutnya pemberian penghargaan terhadap guru, antara lain dengan peningkatan pendapatan (gaji) guru, adanya promosi jabatan, kesempatan karir dan hal lain yang dapat meningkatkan kinerja guru sehingga guru fokus mendidik anak bangsa. Lingkungan sekolah sebagai lingkungan kerja guru masih kurang kondusif, penghargaan terhadap profesi guru juga belum optimal; (5) Pada kenyataannya ada beberapa faktor yang dapat menghambat kinerja guru terkait dengan kondisi lingkungan kerja guru, antara lain letak SMP Negeri 1 Indralaya yang berada di pingir jalan raya lintas timur sumatera yang sangat padat kenderaan pribadi dan angkutan sehingga menimbulkan kebisingan atau polusi suara. Sedangkan penghargaan terhadap kinerja guru juga masih rendah, terutama hal yang berkaitan dengan pendapatan, pengembangan karir dan pengembangan diri.

Tujuan penelitian ini adalah untuk mengetahui pengaruh lingkungan kerja terhadap kinerja guru di SMPN 1 Indralaya, untuk mengetahui pengaruh penghargaan terhadap kinerja guru di SMPN 1 Indralaya dan untuk mengetahui pengaruh secara bersama-sama lingkungan kerja dan penghargaan terhadap kinerja guru di SMPN 1 Indralaya.

\section{METODOLOGI PENELITIAN}

\subsection{Jenis/Desain Penelitian}

Penelitian ini menggunaan metode penelitian kuantitatif, dengan rancangan penelitian berbentuk studi pengaruh, yaitu untuk mengetahui pengaruh antara ketiga variabel penelitian. Penelitian ini terdiri atas dua variabel independen atau variabel bebas, yaitu lingkungan kerja $\left(\mathrm{X}_{1}\right)$ dan penghargaan $\left(\mathrm{X}_{2}\right)$, dan satu variabel dependen atau variabel terikat, yaitu kinerja guru (Y).

\subsection{Populasi Dan Sampel}

Riduwan (2012) mengatakan bahawa populasi adalah objek atau subjek yang memenuhi syarat-syarat tertentu berkaitan dengan masalah penelitian dan berada pada suatu wilayah yang sama. Sedangkan Sugiyono (2012) mengatakan bahwa populasi adalah wilayah generalisasi yang terdiri atas objek atau subjek yang memiliki kualitas dan karakteristik tertentu dan ditetapkan oleh peneliti untuk dipelajari kemudian ditarik kesimpulannya. Berdasarkan dua pengerian di atas, 


\section{JURNAL ILMIAH \\ BINA EDUKASI \\ ISSN 1979-8598 E-ISSN: 2655-8378 \\ http://journal.binadarma.ac.id/index.php/jurnalbinaedukasi \\ Vol. 13, No. 1, Juni 2020, 27--40}

dapat disimpulkan bahwa populasi adalah objek/subjek yang ada pada suatu wilayah dan memiliki karakteristik tertentu untuk dilakukan penelitian. Populasi dari penelitian ini adalah guru di SMPN 1 Indralaya yang berjumlah sebanyak 45 orang.

Sampel adalah bagian dari populasi, yang memiliki karakteristik yang sama dengan populasi tersebut. Sampel adalah bagian dari jumlah dan karakteristik yang dimiliki oleh populasi. penentuan jumlah sampel pada penelitian ini dengan menggunakan penentuan sampel dari populasi oleh Isaac dan Michael (dalam Sugiyono, 2012) dengan taraf kesalahan 5\%. Sampel dari populasi penelitian ditentukan berdasarkan teknik sampling Simple Random Sampling. Pengambilan sampel secara simple dilakukan tanpa memperhatikan strata yang ada dalam populasi tersebut (Sugiyono, 2012). Populasi penelitian ini berjumlah 45 orang guru, maka sampel yang diambil menurut tabel Isaac dan Michael berjumlah 40 orang guru (Sugiyono, 2012).

\subsection{Definisi Operasional Variabel}

Lingkungan Kerja (X1): Segala sesuatu yang ada di sekitar guru yang terdiri 1) lingkungan kerja fisik dengan indikator pencahayaan, pewarnaan, udara, kebersihan, kebisingan dan keamanan. 2) lingkungan kerja non fisik dengan indikator hubungan dengan atasan dan hubungan sesama rekan kerja (Nitisemito, 2010).

Penghargaan (X2): Dimensi penghargaan terdiri dari dua indikator, yaitu relational reward dan transactional reward (Armstrong, 2010).

Kinerja Guru (Y) : Kemampuan guru dalam menjalankan tugas berdasarkan standar kerja yaitu: 1) Perencanaan dengan indikator menentukan tujuan pembelajaran, menyusun bahan ajar, merencanakan kegiatan pembelajaran, menentukan media dan sumber belajar dan menentukan alat evaluasi yang sesuai dengan bahan ajar, 2) Pelaksanaan pembelajaran dengan indikator kemampuan membuka pelajaran, menguasai bahan ajar, menerapkan strategi dan model pembelajaran, pemanfaatan media, menciptakan suasana pembelajaran yang aktif, mengevaluasi pembelajaran, menutup kegiatan pembelajaran, dan memberikan tindak lanjut, 3) Penilaian pembelajaran dengan indikator; merancang alat evaluasi, menggunakan strategi dan metode dalam penilaian, umpan balik siswa (Kemendiknas, 2008).

\subsection{Teknik Analisa Data}

Teknik analisis data dalam penelitian ini menggunakan statistic inferensial, yaitu uji regresi linier sederhana, regresi linier ganda dan uji F. Statistik infrensial adalah proses yang berasal kesimpulan logis dari premis - premis yang diketahui atau dianggap benar. Menurut Kesumawati (2017) bahwa statistika induktif digunakan untuk membuat inferensi terhadap sekumpulan data yang berasal dari suatu sampel. Diperjelas juga menurut Sugiyono (2012) bahwa statistik infrensial di sebut statistik probabilitas, karena kesimpulan yang diberlakukan untuk populasi berdasarkan data sampel itu kebenarannya bersifat peluang. 


\section{JURNAL ILMIAH \\ BINA EDUKASI \\ ISSN 1979-8598 E-ISSN: 2655-8378 \\ http://journal.binadarma.ac.id/index.php/jurnalbinaedukasi \\ Vol. 13, No. 1, Juni 2020, 27--40}

\section{HASIL DAN PEMBAHASAN}

\subsection{Hasil}

\subsubsection{Hasil Uji Validitas}

Pada penelitian ini uji validitas yang digunakan adalah analisis butir (item), yaitu mengorelasikan skor pada setiap item dengan skor total per konstruk (contruct) dan skor total seluruh item. Analisis item/butir tersebut dinyatakan sebagai Corrected Item-Total Correlation dan batas nilai minimal untuk item yang valid pada umumnya adalah 0,230. Sedangkan Azwar (2006) bahwa nilai minimal item yang valid adalah 0,30 (dapat diterima dan dianggap memuaskan), apabila kurang dari 0,30 maka item tersebut dianggap tidak valid dan tidak memuaskan.

Hasil uji validitas variabel lingkungan kerja (X1) adalah dari analisis 25 item (pernyataan) pada kuisioner, terdapat 2 item yang gugur (nilai dibawah 0,30) dan sebanyak 23 item yang valid (nilai diatas 0,30 ). Item yang gugur, yaitu aitem 8 dan aitem 16, sedangkan sisanya adalah item yang valid. 23 item yang valid sudah dapat mewakili dimensi yang diukur pada kuisioner lingkungan kerja.

Hasil uji validitas variabel penghargaan (X2) adalah dari analisis 25 item (pernyataan) pada kuisioner, terdapat 2 item yang gugur (nilai dibawah 0,30) dan sebanyak 23 item yang valid (nilai diatas 0,30 ). Item yang gugur, yaitu aitem 4 dan aitem 8 , sedangkan sisanya adalah item yang valid. 23 item yang valid sudah dapat mewakili dimensi yang diukur pada kuisioner penghargaan.

Hasil uji validitas variabel kinerja guru (Y) adalah dari analisis 27 item (pernyataan) pada kuisioner, terdapat 1 item yang gugur (nilai dibawah 0,30) dan sebanyak 26 item yang valid (nilai diatas 0,30 ). Item yang gugur, yaitu aitem 6, sedangkan sisanya adalah item yang valid. 26 item yang valid sudah dapat mewakili dimensi yang diukur pada kuisioner kinerja guru.

\subsubsection{Hasil Uji Reliabilitas}

Uji reliabilitas ditentukan dengan koefisien Cronbach Alpha. Pengujian ini menentukan konsistensi jawaban responden/subjek atas suatu instrumen penelitian. Reliabilitas dinyatakan oleh koefisien reliabilitas yang angkanya berkisar antara 0 sampai dengan 1,00. Menurut Azwar (2009) semakin tinggi koefisien reliabilitas yang mendekati 1,00 maka semakin tinggi pula reliabilitasnya dan sebaliknya.

Pada nilai koefisien alpha Cronbach kuisioner variabel lingkungan kerja sebesar 0,926 $(>0,60)$. Pada Nilai koefisien alpha Cronbach kuisioner variabel penghargaan sebesar 0,892 $(>0,60)$. Pada Nilai koefisien alpha Cronbach kuisioner variabel kinerja guru sebesar 0,920 $(>0,60)$. Berdasarkan analisa hasil uji reliabilitas tersebut maka dapat dinyatakan bahwa instrumen pengukuran yang digunakan dalam penelitian ini adalah handal (reliabel). 


\section{JURNAL ILMIAH \\ BINA EDUKASI \\ ISSN 1979-8598 E-ISSN: 2655-8378 \\ http://journal.binadarma.ac.id/index.php/jurnalbinaedukasi \\ Vol. 13, No. 1, Juni 2020, 27--40}

\subsubsection{Uji Linieritas}

Cara yang dapat digunakan untuk menentukan tingkat kelinearan adalah dengan cara analisis pada lajur deviation from linearity, sedangkan untuk menentukan keberartian arah regresinya, dapat memperhatikan hasil analisis pada lajur linearity. Jika nilai sig Dev from Linearity lebih besar dari 0,05 maka hubungan variabel bebas dengan variabel terikat linear. Dan sebaliknya jika nlai sig Dev from Linearity lebih kecil dari 0,05 maka hubungan kedua variabel tidak linear.

Nilai signifikansii yang diperoleh dari uji linearitas menunjukan bahwa antara variabel lingkungan kerja dan kinerja guru adalah 0,893. Karena nilai 0,893>0,05 maka hubungan keduanya dikatakan linear. Sedangakan Nilai signifikansii yang diperoleh dari uji linearitas antara variable penghargaan dan kinerja guru adalah 0,389. Karena nilai 0,389 >0,05 maka hubungan keduanya dikatakan linear.

\subsubsection{Hasil Uji Hipotesis}

Ada tiga hipotesis yang diajukan dalam penelitian ini, yaitu 1) Terdapat pengaruh lingkungan kerja terhadap kinerja guru di SMPN 1 Indralaya; 2) Terdapat pengaruh penghargaan terhadap kinerja guru di SMPN 1 Indralaya; dan 3) Terdapat pengaruh secara bersama-sama lingkungan kerja dan penghargaan terhadap kinerja guru di SMPN 1 Indralaya. Untuk melakukan pengujian terhadap hipotesis yang diajukan dilakukan dengan menguji koefisien jalur masingmasing variabel. Koefisien jalur menunjukkan pengaruh langsung dari setiap variabel (Gaspers dalam Cahyasumirat, 2006). Hasil pengujian hipotesis berdasarkan olah data dengan SPSS-19.

Hipotesis 1 (H1) menyatakan bahwa lingkungan kerja berpengaruh terhadap kinerja guru. Hal tersebut dapat dilihat dari nilai standard coefficients Beta (r) sebesar 0.097 dengan $p$ sebesar 0,213 ( $p>0.05$ ), berarti hasilnya tidak signifikan (pengaruh signifikan apabila $\mathrm{p}<0,05$ ). Dengan demikian dapat disimpulkan bahwa hipotesis 1 ditolak. Ini berarti bahwa tidak ada pengaruh lingkungan kerja terhadap kinerja guru di SMPN 1 Indralaya.

Hipotesis $2(\mathrm{H} 2)$ menyatakan bahwa penghargaan berpengaruh terhadap kinerja guru. Hal tersebut dapat dilihat dari nilai standard coefficients Beta (r) sebesar 0.739 dengan $p$ sebesar 0.000 $(p<0.05)$, berarti hasilnya berpengaruh signifikan. Dengan demikian dapat disimpulkan bahwa hipotesis 2 diterima/terbukti. Ini berarti bahwa terdapat pengaruh signifikan penghargaan terhadap kinerja guru di SMPN 1 Indralaya.

Hipotesis 3 (H3) menyatakan bahwa lingkungan kerja dan penghargaan secara bersamasama berpengaruh terhadap kinerja guru. Berdasarkan hasil analisis data output SPSS-19 diperoleh nilai F-hitung sebesar 50,869 dengan signifikansi F sebesar 0,000. Dengan menggunakan tingkat signifikansi sebesar 5\%, maka nilai tabel dengan df $1=2$ dan df $2=n-k-1=$ 40-2-1 = 37, maka diperoleh F-tabel sebesar 2,47. Hasil uji keberartian korelasi dengan uji F 


\section{JURNAL ILMIAH \\ BINA EDUKASI \\ ISSN 1979-8598 E-ISSN: 2655-8378 \\ http://journal.binadarma.ac.id/index.php/jurnalbinaedukasi \\ Vol. 13, No. 1, Juni 2020, 27--40}

dihasilkan F hitung yang dihasilkan sebesar 50,868 lebih besar dari $\mathrm{F}$ tabel sebesar 2,47 atau $50,868>2,47$, maka dapat dikatakan bahwa model pengaruh antara $\mathrm{X} 1$ dan $\mathrm{X} 2$ dengan $\mathrm{Y}$ signifikan secara statistik sehingga dapat dikatakan bahwa regresi yang diperoleh adalah berarti. Berdasarkan analisa data tersebut bahwa F-hitung > F-tabel $(50,869>2,47)$ dengan dengan signifikansi F sebesar 0,000 Ini berarti bahwa terdapat pengaruh signifikan secara bersama-sama lingkungan kerja dan penghargaan terhadap kinerja guru di SMPN 1 Indralaya.

\subsection{Pembahasan}

Berdasarkan hasil uji hipotesis diperoleh nilai standard coefficients Beta (r) sebesar 0.097 dengan $p$ sebesar 0,213 ( $p>0.05)$. Hal tersebut menunjukkan tidak ada pengaruh/tidak signifikan (pengaruh signifikan apabila $\mathrm{p}<0,05$ ), dengan demikian dapat disimpulkan bahwa hipotesis 1 ditolak. Tidak ada pengaruh lingkungan kerja terhadap kinerja guru di SMPN 1 Indralaya, ini berarti bahwa lingkungan kerja yang baik tidak serta merta akan diikuti dengan meningkatnya kinerja yang baik pula. Lingkungan kerja dapat mempengaruhi berbagai hal termasuk kinerja guru, lingkungan yang kondusif akan memberi kenyamanan dalam bekerja. Nitisemito (2010) faktor yang ada dalam lingkungan kerja sangat luas sehingga sulit untuk disebutkan keseluruhannya, faktor-faktor tersebut antara lain : kebersihan, pertukaran udara, pencahayaan, musik, keamanan, keamanan dan kebisingan. Faktor-faktor tersebut berpengaruh terhadap motivasi pekerja yang berdampak pada kinerja.

Penelitian ini tidak sejalan dengan teori dan hasil penelitian Rahmawati, dkk (2014) yang dapat membuktikan bahwa ada pengaruh linkungan kerja fisik dan lingkungan kerja non fisik terhadap kinerja karyawan. Faktor kinerja berkaitan dengan motivasi, kepuasan kerja, stres kerja, kondisi fisik pekerjaan, kompensasi, dan desain pekerjaan (Handoko, 2009). Faktor-faktor tersebut saling berkaitan dengan keadaan lingkungan kerja, dimana keadaan nyata di lingkungan kerja berpengaruh langsung terhada kinerja, hal ini dapat terjadi karena sebenarnya manusia menilai apakah lingkungan kerja dapat memberikan berbagai macam kebutuhan baik secara fisik maupun non-fisik guna untuk pemenuhan kebutuhan selama bekerja. Ketika lingkungan kerja dapat menunjang hal-hal tersebut, maka kinerja akan meningkat.

Berdasarkan konsep teori bahwa lingkungan kerja berpengaruh terhadap kinerja guru, akan tetapi hasil penelitian ini menghasilkan hal yang berbeda dikarenakan guru di SMP Negeri 1 Indralaya acuh dengan kondisi lingkungan sekolah yang ada sekarang ini. Pimpinan dalam hal ini adalah kepala sekolah, juga kurang memperhatikan lingkungan kerja bagi para guru agar dapat memaksimalkan kemampuannya untuk memberikan yang terbaik bagi sekolah. Berkaitan dengan lingkungan kerja/lingkungan sekolah yang belum kondusif dan belum nyaman dapat menyebabkan turunnya kinerja guru. Seorang guru diwajibkan dengan tugas dan kewajibannya di sekolah dan tidak diperkenankan untuk kerja sampingan. Dimana apabila guru tidak melakukan 


\section{JURNAL ILMIAH \\ BINA EDUKASI \\ ISSN 1979-8598 E-ISSN: 2655-8378 \\ http://journal.binadarma.ac.id/index.php/jurnalbinaedukasi \\ Vol. 13, No. 1, Juni 2020, 27--40}

pekerjaan yang sebenarnya sesuai dengan tugas dan fungsi sebagai seorang guru, dan lingkungannya tidak mendukung kebutuhan selama ia bekerja, maka ia tidak akan mendapatkan bayaran yang diharapkan atau bahkan terancam kehilangan pekerjaannya. Hal tersebut mengindikasikan bahwa lingkungan kerja yang mestinya berpengaruh positif terhadap kinerja, justru memberikan efek pada penurunan kinerja guru.

Berdasarkan hasil uji hipotesis 2 bahwa penghargaan berpengaruh terhadap kinerja guru. Nilai standard coefficients Beta $(\mathrm{r})$ sebesar 0.739 dengan $p$ sebesar 0.000 ( $p<0.05)$, berarti berpengaruh signifikan. Dengan demikian dapat disimpulkan bahwa hipotesis 2 diterima/terbukti. Ini berarti bahwa terdapat pengaruh signifikan penghargaan terhadap kinerja guru di SMPN 1 Indralaya.

Memperhatikan hasil uji hipotesis 2 di atas membuktikan bahwa penghargaan (reward) merupakan salah satu elemen penting dan dapat dimanfaatkan organisasi untuk memotivasi pegawai agar dapat memberikan kontribusi yang maksimal pada organisasi/instansi dalam hal ini peningkatan kinerja. Menurut Armstrong (2010) bahwa penghargaan memiliki makna yang luas dan tidak hanya terfokus pada finansial saja. Pada penelitian ini dimensi penghargaan yang diteliti meliputi dua indikator, yaitu relational reward dan transactional reward.

Penghargaan Relasional (relational reward) pada umumnya hampir serupa dengan penghargaan instrinsik, yaitu penghargaan yang berpengaruh dalam diri pegawai itu sendiri, penghargaan ini bersifat non finansial dan tidak berwujud. Penghargaan ini merupakan nilai positif atau rasa puas pegawai terhadap dirinya sendiri karena telah menyelesaikan suatu tugas yang baginya cukup menantang. Teknik-teknik pemerkayaan pekerjaan, seperti pemberian peran dalam pengambilan keputusan, tanggung jawab yang lebih besar, kebebasan dan keleluasaan kerja yang lebih besar dengan tujuan untuk meningkatkan harga diri pegawai serta pengembangan karir secara intrinsik merupakan imbalan bagi pegawai. Penghargaan relasional ini juga berkaitan dengan pembelajaran dan pengembangan yang diterima pegawai, termasuk juga bagaimana proses pengembangan karir dan pengalaman kerja di dalamnya. Bedasarkan hasil penelitian ini dapat disimpulkan bahwa untuk miningkatkan kinerja pegawai (guru,) seharusnya guru diberi peran dalam pengambilan keputusan, guru diberi tanggung jawab lebih besar, diberi kebebasan dan keleluasaan dalam bekerja serta proses pengembangan karir yang jelas dan terukur. Penghargaan transkasional merupakan istilah lain dari ektrinsic reward, yaitu penghargaan pada pegawai yang ada wujudnya dan biasanya diberikan dalam bentuk finansial atau memberi manfaat bagi pegawai yang bersangkutan.

Penghargaan transaksional yang dikategorikan finansial ini biasanya mencakup : gaji pokok, upah lembur, pembayaran insentif, tunjangan dan bonus. Sedangkan penghargaan transaksional yang diaktegorikan manfaat mencakup hal-hal yang berkaitan dengan dana pensiun, jaminan sosial, asuransi, libur dan cuti kerja. Berdasarkan hasil penelitian ini membuktikan bahwa 


\section{JURNAL ILMIAH \\ BINA EDUKASI \\ ISSN 1979-8598 E-ISSN: 2655-8378 \\ http://journal.binadarma.ac.id/index.php/jurnalbinaedukasi \\ Vol. 13, No. 1, Juni 2020, 27--40}

penghargaan berupa peningkatan finansial guru dapat meningkatkan kinerja guru. Penelitian ini sejalan dengan teori dan hasil penelitian Prabu, dkk (2016) yang dapat membuktikan bahwa ada pengaruh penghargaan dan motivasi terhadap kinerja karyawan.

Berdasarkan hasil uji hipotesis 3 diperoleh nilai F-hitung sebesar 50,869 dengan signifikansi F sebesar 0,000. Hasil uji keberartian korelasi dengan uji F dihasilkan F hitung yang dihasilkan sebesar 50,868 lebih besar dari $\mathrm{F}$ tabel sebesar 2,47 atau 50,868>2,47, maka dapat dikatakan bahwa model pengaruh antara X1 dan X2 dengan Y signifikan secara statistik sehingga dapat dikatakan bahwa regresi yang diperoleh adalah berarti. Berdasarkan analisa data tersebut di atas bahwa F-hitung > F-tabel $(50,869>2,47)$ dengan dengan signifikansi $\mathrm{F}$ sebesar 0,000 Ini berarti bahwa terdapat pengaruh signifikan secara bersama-sama lingkungan kerja dan penghargaan terhadap kinerja guru di SMPN 1 Indralaya. Dengan demikian dari hasil penelitian ini memberikan informasi bahwa lingkungan kerja dan penghargaan secara bersama-sama memberikan kontribusi yang signifikan terhadap kinerja guru, artinya lingkungan kerja yang baik, nyaman dan aman disertai dengan semakin tingginya pemberian penghargaan, maka akan semakin tinggi atau baik pula kinerja guru. Sebaliknya makin buruk kondisi lingkungan kerja dan makin rendah penghargaan, maka akan semakin rendah pula kinerja guru. Oleh karena itu skor lingkungan kerja dan skor penghargaan secara bersama-sama dapat dijadikan acuan untuk menentukan tinggi rendahnya skor kinerja guru di SMPN 1 Indralaya.

Bila dari kedua variabel independen tersebut digunakan untuk meningkatkan kinerja guru, maka itu merupakan langkah yang sangat strategis karena secara bersama-sama kedua variabel itu memberi pengaruh yang signifikan terhadap kinerja guru. Sementara itu variabel lingkungan kerja secara mandiri telah memberikan kontribusi sebesar 9,7\% terhadap peningkatan kinerja guru di SMPN 1 Indralaya, sisanya sebesar 90,3\% disebabkan oleh variabel lain. Ini artinya bahwa faktor lingkungan kerja tidak terlalu besar dalam menyumbang peningkatan kinerja guru, faktor pengaruhnya kurang dari sepuluh persen. Sedangkan variabel penghargaan secara mandiri telah memberikan kontribusi sebesar 93,7\% terhadap peningkatan kinerja guru, dan sisanya sebesar $6,3 \%$ disebabkan oleh variabel lain. Ini artinya bahwa faktor penghargaan sangat besar dalam menyumbang peningkatan kinerja guru.

Menariknya ketika variabel lingkungan kerja secara bersama-sama dengan variabel penghargaan, maka keduanya secara bersama-sama memberikan kontribusi terhadap peningkatan kinerja guru sebesar 58,2\%. Ini angka yang sangat tinggi karena lebih dari lima puluh persen faktor lingkungan kerja secara bersama dengan faktor penghargaan mempengaruhi kinerja guru di SMPN 1 Indralaya. Hanya sisa 41,8\% peningkatan kinerja guru disebabkan karena faktor lain. Dari hasil analisis ini menunjukkan bahwa tampak perbandingan kinerja guru di SMPN 1 Indralaya antara sebelum dan setelah pemberian penghargaan, dimana rata-rata kinerja guru pasca pemberian penghargaan justru mengalami peningkatan dibandingkan sebelum ada program 


\section{JURNAL ILMIAH \\ BINA EDUKASI \\ ISSN 1979-8598 E-ISSN: 2655-8378 \\ http://journal.binadarma.ac.id/index.php/jurnalbinaedukasi \\ Vol. 13, No. 1, Juni 2020, 27--40}

pemberian penghargaan. Kondisi ini menuntut pemerintah agar dilakukan evaluasi terhadap program pemberian penghargaan dan untuk melihat apakah sesuai dengan yang direncanakan atau tidak. Disamping itu perlu ada pola pembinaan yang terpadu dan berkelanjutan kepada guru-guru yang telah menerima penghargaan dan kesejahteraan. Lebih jauhnya, diperlukan badan atau lembaga independen yang mampu mengawasi program pemberian penghargaan pada guru mulai dari proses pelaksanaan sampai kepada pembinaan guru.

Penelitian ini telah dilakukan dengan cermat berdasarkan metode dan prosedur yang sesuai dengan jenis penelitian. Namun kesempurnaan hasil merupakan hal yang tidak mudah diwujudkan. Hasil penelitian ini adalah hasil terbaik saat ini, meskipun dengan semua keterbatasan dan kelemahan yang ditemuai saat proses penelitian yang dilakukan. Penelitian ini tidak terlepas dari kelemahan dan keterbatasan yang tidak dapat dihindari meskipun instrumen yang dirancang telah dilakukan uji validitas dan reliabilitasnya. Namun kesungguhan dan kebenaran umpan balik yang diberikan responden sulit dikontrol dan dikendalikan oleh peneliti. Terutama aspek kejujuran dan kesungguhan dalam mengisi instrumen. Sebab bisa saja respon ataupun umpan balik yang diberikan terhadap butir-butir kuisioner yang diajukan tidak sesuai dengan keadaan yang sebenarnya, dikarenakan adanya kecemasan responden bahwa pengisian instrumen penelitian akan berpengaruh terhadap kondisi mereka jika menjawab sesuai dengan keadaan yang sebenarnya. Meskipun dari awal peneliti telah menginformasikan bahwa data yang diberikan benar-benar hanya akan digunakan untuk penelitian ini dan tidak akan berpengaruh sama sekali pada kondisi mereka. Oleh karena itu peneliti perlu mendapatkan asumsi bahwa respon yang diberikan terhadap buitr-buitr pernyataan instrumen sudah dapat memberikan sumbangan gambaran yang sebenarnya sesuai dengan apa yang hendak diungkapkan melalui instrumen penelitian.

\section{SIMPULAN}

Berdasarkan analisis hasil penelitian dan pembahasan data melalui pembuktian hipotesis yang meliputi tiga variabel yaitu lingkungan kerja $\left(\mathrm{X}_{1}\right)$, penghargaan $\left(\mathrm{X}_{2}\right)$ dan Kinerja Guru $(\mathrm{Y})$, maka dapat disimpulkan bahwa pertama lingkungan kerja tidak memberikan pengaruh terhadap kinerja guru di SMPN 1 Indralaya. Ini berarti bahwa lingkungan kerja tempat guru mengajar, dalam hal ini adalah lingkungan sekolah tidak memberikan efek pada peningkatan kinerja guru. Kondisi seperti ini bisa saja terjadi apabila guru di SMP Negeri 1 Indralaya acuh dengan kondisi lingkungan sekolah yang ada sekarang ini, atau bisa juga terjadi karena faktor pimpinan. Pimpinan dalam hal ini adalah kepala sekolah, juga kurang memperhatikan lingkungan kerja bagi para guru.

Kedua adalah penghargaan pada guru memberi pengaruh terhadap kinerja guru di SMPN 1 Indralaya. Artinya semakin tinggi penghargaan yang diberikan pada guru, maka kinerja guru 


\section{JURNAL ILMIAH \\ BINA EDUKASI \\ ISSN 1979-8598 E-ISSN: 2655-8378 \\ http://journal.binadarma.ac.id/index.php/jurnalbinaedukasi \\ Vol. 13, No. 1, Juni 2020, 27--40}

semakin meningkat. Penghargaan pada guru ini, apalagi terkait dengan finansial sangat tergantung dengan kebijakan yang dibuat oleh pemerintah. Dan ketiga berdasarkan hasil penelitian ini bahwa lingkungan kerja secara mandiri tidak memberikan pengaruh terhadap kinerja guru, akan tetapi lingkungan kerja dan penghargaan secara bersama-sama berpengaruh terhadap kinerja guru di SMPN 1 Indralaya. Ini berarti bahwa perbaikan lingkungan kerja dan pemberian penghargaan pada guru akan meningkatakan kinerja guru.

\section{DAFTAR PUSTAKA}

Armstrong, Michael. (2010). Employee Reward Management and Practice (2nd edition). London: Kogan Page.

Azwar, S. (2006). Reliabilitas dan Validitas. Yogyakarta: Pustaka Pelajar.

--------. (2009). Penyusunan Skala Psikologi. Yogyakarta: Pustaka Pelajar.

Barnawi dan Mohammad Ariffin. (2014). Kinerja guru Profesional. Yogyakarta: AR-RUZZ MEDIA.

Cahyasumirat, Gunawan. (2006). Pengaruh Frofesionalisme dan Komitmen Organisasi Terhadap Kinerja Internal Auditor, Dengan Kepuasan Kerja Sebagai Variabel Intervering (Studi Empiris Pada internal Auditor PT Bank ABC). Tesis tidak dipublikasikan. Semarang : Program Pascasarjana Universitas Diponegoro.

Edwardin, L.T.A.S. (2006). Analisis Pengaruh Kompetensi Komunikasi, Kecerdasan Emosional, dan Budaya Organisasi terhadap Kinerja Karyawan (Studi Pada PT Pos Indonesia (Persero) Se Kota Semarang). Tesis tidak dipublikasikan. Semarang: Pascasarjana Magister Manajemen Universitas Diponegoro.

Handoko, T. Hani. (2009). Manajemen Personalia dan Sumber Daya Manuasia. Yogyakarta: BPFE.

Harapan, Edi. (2018). Pembiayaan Pendidikan ; Teori dan Praktek Menggali Sumber Pembiayaan Pendidikan Nasional. Palembang: Noer Fikri.

Kemendiknas. (2008). Alat Penilaian Kemampuan Guru (APKG).

Kesumawati, Nila dan Icwan Aridanu. (2017). Statistik Parametrik Penelitian Pendidikan. Palembang: Noer Fikri.

Mulyasa. (2013). Manajemen Berbasis Sekolah. Bandung: PT Remaja Rosdakarya.

Nitisemito, Alex S. (2010). Manajemen Personalia, Manajemen Sumber Daya Manusia. Jakarta: Ghalia Indonesia.

Nnaji-Ihedinmah, Chijioke \& Egbunike, Francis, Chinedu. (2015). Effect of Rewards on Employee Performance in Organizations: A Study of Selected Commercial Banks in Awka Metropolis. European Journal of Business and Management, Vol. 7 No. 4. Hal. 80-88. 
Peraturan Menteri Pendidikan Nasional RI No. 35. (2010). Tentang Petunjuk Teknis Pelaksanaan Jabatan Fungsional Guru Dan Angka Kreditnya.

Prabu, Aldila Saga dan Dewie Tri Wijayanti. (2016). Pengaruh Penghargaan dan Motivasi Terhadap Kinerja Karyawan (Studi Pada Divisi Penjulan PT United Motor Center Suzuki Ahmad Yani, Surabaya). Jurnal Ekonomi Bisnis dan Kewirausahaan. Vol. 5. No. 2-2016. Hal. 104-117.

Rahmawati, Nila Pima. Bambang Swasto dan Arik Prasetya. (2014). Pengaruh Lingkungan Kerja Terhadap Kinerja Karyawan (Studi Pada Karyawan Kantor Pelayanan Pajak Pratama Malang Utara). Jurnal Administrasi Bisnis (JAB). Vol. 8. No. 2 Maret 2014. Hal. 1-9.

Riduwan. (2012). Dasar-dasar Statistika. Bandung: Alfabeta.

Rivai, Veithzal. (2015). Manajemen Sumber Daya Manusia Untuk Perusahaan, Dari Teori Ke Praktek. Jakarta : PT. Rajagrafindo Persada.

Sugiyono. (2012). Statistika untuk Penelitian. Bandung: Penerbit Alfabeta.

Supardi. (2013). Kinerja Guru. Jakarta: Rajawali Pers.

Undang - Undang Nomor 14 tahun 2005 tentang Guru dan Dosen.

Usman, Husaini. (2009). Manajemen Teori Praktik dan Riset Pendidikan. Jakarta: Bumi Aksara. 